\title{
The Aging Motor System as a Model for Plastic Changes of GABA-Mediated Intracortical Inhibition and Their Behavioral Relevance
}

\author{
Kirstin-F. Heise, ${ }^{1}$ Maximo Zimerman, ${ }^{1}$ Julia Hoppe, ${ }^{1}$ Christian Gerloff, ${ }^{1}$ Karl Wegscheider, ${ }^{2}$ and Friedhelm C. Hummel ${ }^{1}$ \\ ${ }^{1}$ Brain Imaging and NeuroStimulation (BINS) Laboratory, Department of Neurology, and ${ }^{2}$ Department of Medical Biometry and Epidemiology, University \\ Medical Center Hamburg-Eppendorf, 20246 Hamburg, Germany
}

\begin{abstract}
Since $\mathrm{GABA}_{\mathrm{A}}$-mediated intracortical inhibition has been shown to underlie plastic changes throughout the lifespan from development to aging, here, the aging motor system was used as a model to analyze the interdependence of plastic alterations within the inhibitory motorcortical network and level of behavioral performance. Double-pulse transcranial magnetic stimulation (dpTMS) was used to examine inhibition by means of short-interval intracortical inhibition (SICI) of the contralateral primary motor cortex in a sample of 64 healthy right-handed human subjects covering a wide range of the adult lifespan (age range 20 - 88 years, mean $47.6 \pm 20.7,34$ female). SICI was evaluated during resting state and in an event-related condition during movement preparation in a visually triggered simple reaction time task. In a subgroup $(N=23)$, manual motor performance was tested with tasks of graded dexterous demand.

Weak resting-state inhibition was associated with an overall lower manual motor performance. Better event-related modulation of inhibition correlated with better performance in more demanding tasks, in which fast alternating activation of cortical representations are necessary. Declining resting-state inhibition was associated with weakened event-related modulation of inhibition. Therefore, reduced resting-state inhibition might lead to a subsequent loss of modulatory capacity, possibly reflecting malfunctioning precision in $\mathrm{GABA}_{\mathrm{A}}$ ergic neurotransmission; the consequence is an inevitable decline in motor function.
\end{abstract}

\section{Introduction}

The balanced activation of excitation and inhibition is a crucial prerequisite for effective neuronal processing (Miura et al., 2007; Le Roux et al., 2008). Alterations in GABA-mediated inhibitory tone are discussed as one major mechanism through which the cell's gain is changed and synaptic integration is modified (Semyanov et al., 2004). The result is a subsequent change in homeostatic regulation of phasic inhibition of pyramidal cells (Semyanov et al., 2003), possibly effecting fine-tuning and shaping of neuronal firing (Farrant and Nusser, 2005). In particular, the reduction of inhibition is important for the modulation of neuronal circuits, and it is hypothesized to present an evolutionary conserved mechanism to augment plastic properties (Baroncelli et al., 2011; Imbrosci and Mittmann, 2011). An open question is still unsolved, whether the reduction of inhibition eventually reaches a ceiling, above which it results in functional costs on the systems level. In contrast to rapid short-term changes, a prevailing level of disinhibition could result in

Received Aug. 26, 2012; revised Nov. 5, 2012; accepted Dec. 11, 2012.

Author contributions: K.-F.H., C.G., K.W., and F.C.H. designed research; K.-F.H., M.Z., J.H., and F.C.H. performed research; K.-F.H., K.W., and F.C.H. analyzed data; K.-F.H., C.G., and F.C.H. wrote the paper.

This research was supported by a grant from the Alexander von Humboldt Foundation (Feodor-Lynen) to F.C.H., the Forschungsförderungsfonds Medizin of the University of Hamburg (NWF-04/07 to F.C.H.;NWF-10/04 to K.-F.H.), and by the SFB 936 C4 (to F.C.H.) of the German Research Foundation. We thank Martina Niehoff for helping with data acquisition and Jan-Frederik Feldheim for helping with data management.

Correspondence should be addressed to Dr. Friedhelm C. Hummel, Department of Neurology, University Medical Center Hamburg-Eppendorf, 20246 Hamburg, Germany. E-mail: f.hummel@uke.uni-hamburg.de.

DOI:10.1523/JNEUROSCI.4094-12.2013

Copyright $\odot 2013$ the authors $\quad 0270-6474 / 13 / 339039-11 \$ 15.00 / 0$ a loss of dynamic modulation, accordingly resulting in deficient synchronicity and precision in neuronal firing as shown in single-cell and slice models (Chagnac-Amitai and Connors, 1989; Bacci and Huguenard, 2006; Manseau et al., 2010) and predicted by computational modeling (Vida et al., 2006; Miura et al., 2007).

The nervous system underlies plastic changes from development to aging, in response to experience, and in disease. Regarding GABAergic neurotransmission, alterations in receptor subunit composition (Caspary et al., 1999; Yu et al., 2006b; Schmidt et al., 2010) and declining neurotransmitter synthesis (Ling et al., 2005) have been found to occur as a function of age in several neocortical structures in animal models. Whereas disease- and age-related reduction of inhibition in the sensory system has been related to deterioration of behavior, such as impaired tactile acuity or diminished visual and auditory signal-to-noise coding (Leventhal et al.; Yu et al., 2006a; Hua et al., 2008; David-Jürgens and Dinse, 2010), the association between reduced GABAergic inhibition and behavioral consequences in the motor domain is less clear (Grachev et al., 2001; Imbrosci and Mittmann, 2011; Stagg et al., 2011).

The reduction of inhibitory tone is important for rapid experience-dependent plasticity as in motor learning (Floyer-Lea et al., 2006), its direct relevance for motor performance, however, is still elusive.

Here, the aging motor system was used as a model for plastic alterations of GABAergic inhibition to analyze its behavioral relevance.

Double-pulse transcranial magnetic stimulation (dpTMS) allows noninvasive investigation of inhibitory networks mediated 
Table 1. Summary of the experimental conditions, graded according to the demands of the specific stages of sensorimotor processing, i.e., cognitive, premotor, and motor processing

\begin{tabular}{|c|c|c|c|c|c|c|}
\hline \multirow[b]{3}{*}{ Task } & \multirow{2}{*}{\multicolumn{2}{|c|}{ Sensory processes }} & \multirow[b]{3}{*}{$\begin{array}{l}\text { Cognitive processes } \\
\text { Response selection }\end{array}$} & \multirow{3}{*}{$\begin{array}{l}\text { Premotor processes } \\
{[\text { Warning cue } \longleftrightarrow \text { imperative stimulus] "priming }} \\
\text { the movement representations of the prepared } \\
\text { response in foreperiod" }\end{array}$} & \multicolumn{2}{|l|}{ Motor processes } \\
\hline & & & & & \multicolumn{2}{|l|}{ Response generation } \\
\hline & Timing & $\begin{array}{l}\text { Stimulus } \\
\text { processing } \\
\text { load }\end{array}$ & & & $\begin{array}{l}\text { Coordinate biomechanic } \\
\text { movement properties: effector/ } \\
\text { degrees of freedom }\end{array}$ & $\begin{array}{l}\text { Processing } \\
\text { demand }\end{array}$ \\
\hline 1FT & Intrinsic & No & No & No & $1 / 2$ & Simple \\
\hline $2 \mathrm{FT}$ & Intrinsic & No & No/yes & No & $2 / 2$ & Complex \\
\hline SRT & Extrinsic & Low & No & No & $1 / 1$ & Simple \\
\hline CRT & Extrinsic & Higher & Yes & Yes & $1 / 2$ & Complex \\
\hline
\end{tabular}

through the $\mathrm{GABA}_{\mathrm{A}}$ receptor at the level of interneurons within the primary motor cortex (Kujirai et al., 1993; see Materials and Methods). Whereas resting state is dominated by an inhibitory tone, event-related analyses have shown a task-specific modulation of inhibition in terms of fast short-term release of inhibition before movement onset (Reynolds and Ashby, 1999; Sinclair and Hammond, 2008).

The question was whether resting-state inhibition is associated with the event-related modulation of inhibition. The underlying hypothesis was that inhibitory networks are altered in the same amount as fast and precise motor behavior if the assumption of a causal relationship was true.

\section{Materials and Methods}

Participants. Sixty-four healthy subjects (age range 20-88 years, average $47.63 \pm 20.71 \mathrm{SD}, 34$ female, all right-handed) gave full written informed consent to participate in the experiment in accordance with the local ethics committee approval. All subjects were right-handed as evaluated with the Edinburgh handedness scale (Oldfield, 1971). Before the experimental sessions, all participants were screened regarding neurological or psychiatric illness, other medical conditions, and medication intake interfering with the experimental procedures or outcome (Rossi et al., 2009). Transcranial magnetic stimulation was applied over the primary motor cortex (M1) contralaterally to the first dorsal interosseus (FDI) muscle in 33 cases over the left hemisphere and in 31 cases over the right hemisphere. A subset of the present data was part of previously published control data [total 15: $N=5$ (Hummel et al., 2009), $N=10$ (Heise et al., 2010)].

Transcranial magnetic stimulation and EMG recording. Sound evidence from pharmacological studies supports the idea that with double-pulse transcranial magnetic stimulation (TMS) of $3 \mathrm{~ms}$ interstimulus interval (short-interval intracortical inhibition, SICI), it is possible to investigate inhibitory networks mediated through the $\mathrm{GABA}_{\mathrm{A}}$ receptor at the level of interneurons within M1 (Kujirai et al., 1993; Ziemann et al., 1996a,b; Hanajima et al., 1998; Di Lazzaro et al., 2000; Fisher et al., 2002; Ilić et al., 2002; Roshan et al., 2003; Di Lazzaro et al., 2005a,b; Muller-Dahlhaus et al., 2008). However, considering the limits of this method, one has to keep in mind that the $\mathrm{GABA}_{\mathrm{A}}$ ergic system is influenced by and closely related to other neurotransmitter systems. Methods for resting-state and event-related measurement of SICI have been described in detail previously (Hummel et al., 2009; Heise et al., 2010).

Behavioral experiment. In a separate session, dexterous manual performance was tested without TMS in a subgroup $(N=23)$ randomly selected from the original sample. The driving hypothesis in task selection was that fast and precise recruitment of specific motorcortical representations with synchronous inhibition of nonrelevant cortical representations would necessitate maximum inhibitory control (Stinear and Byblow, 2003; Byblow and Stinear, 2006; Beck and Hallett, 2010).

Since the primary focus was set on motor processing rather than sensory or higher order cognitive processes, the design of the tasks incorporated on the one hand overall low sensory processing demands for the visual stimuli. On the other hand tasks were kept simple with the purpose of avoiding high cognitive load. To differentiate the degree to which motorcortical inhibition contributes to motor functional decline, the experimental conditions were graded according to the demands of the specific stages of sensorimotor processing, i.e., cognitive, premotor, motor processing (Table 1). All tasks were chosen as to incorporate FDI muscle activity.

The primary target task was an alternating individual finger-tapping task requiring fast contraction and release of agonist and antagonist muscles of the two different end effectors index and little finger. Alternating finger tapping $(2 \mathrm{FT})$ and solitary index finger tapping (1FT) were recorded over $3 \times 10$ s between GO- and STOP-signal. In both tasks the subjects were instructed to tap as fast and as precise as possible on predefined buttons of a 4-digit keypad. The simple reaction time task (SRT) required an index finger key press on a standard computer keyboard in response to a target stimulus with intertrial intervals jittering between 1 and $7 \mathrm{~s}$. A total of 110 trials were collected per subject and hand.

During the choice-reaction time task (CRT), subjects were asked to respond as fast as possible to a (neutrally pre-cued) target stimulus indicating either a left or a right index finger key press starting from a standardized middle position on a standard keyboard. Intertrial intervals jittered between 1 and $6 \mathrm{~s}$. A total of 90 trials were collected per subject and hand.

Visual cues were provided on a 20 inch computer screen by Presentation software (Neurobehavioral Systems), also used to record response parameters (number of key presses, reaction time, key-press intervals, key selection) for off-line analyses.

For all experiments participants were seated with forearms supported on a table. Hand positioning on the keyboard assured movement of respective fingers only. Any whole hand, wrist, or arm movements were restricted throughout all behavioral experiments. Participants were tested on both sides. In each subject the side contralateral to the respective hemisphere tested with TMS was tested first and exclusively entered into further analyses.

Data processing. EMG-data showing muscle activity before TMS pulses were discarded from further analysis after visual inspection. Motor-evoked potential (MEP) amplitudes were measured peak-topeak. As it is standard practice SICI was normalized to the corresponding unconditioned MEP (SICI = conditioned MEP/unconditioned MEP $\times$ $100)$ at either resting-state $\left(\mathrm{SICI}_{\text {rest }}\right)$ or respective pre-move time zones ( $\left.\mathrm{SICI}_{\text {move }}\right)$.

Behavioral data were processed using a customized automated log file parser to calculate outcome variables (1FT, SRT, CRT: response time for correct key presses, 2FT: number of valid transitions between index and little finger).

Statistical analyses. Student's $t$ test (two-tailed) and one-way ANOVA were used for univariate data analyses regarding between-group differences of stimulus intensities (expressed as percentage of maximum stimulator output, \% MSO) and premovement reaction time for HEMISPHERES (dominant, nondominant) and SEX (male, female).

Linear mixed effects modeling (LME) was used for multivariate data analyses of resting-state and event-related TMS data. To estimate variances of random effects, restricted maximum likelihood (REML) criteria were used. Model selection was based on Bayesian Information Criterion (BIC) for model comparison; normalized residuals based on REML fit served for model validation (Brown and Prescott, 2006; Pinheiro and Bates, 2009).

In the case of resting-state data $\left(\mathrm{SICI}_{\text {rest }}\right)$, hemispheric (Rossini et al., 1992; Sale and Semmler, 2005; Smith et al., 2009) and sex differences 
Table 2. Baseline characteristics and stimulus intensities for the whole group (ALL, $N=64$ ) and for respective subgroups

\begin{tabular}{|c|c|c|c|c|c|c|c|c|}
\hline & $N$ & AGE & SEX & rMT (\% MSO) & CS intensity (\% MSO) & TS intensity (\% MSO) & SpMEP (mV) & Premove RT (ms) \\
\hline ALL & 64 & $47,62 \pm 20,71(20-88)$ & 34 female & $44,02 \pm 8,19$ & $34,80 \pm 6,39$ & $51,08 \pm 9,15$ & $0.89 \pm 0.77$ & $199.46 \pm 30.71$ \\
\hline \multicolumn{9}{|l|}{ HEMISPHERES } \\
\hline Left & 33 & $47,52 \pm 20,99(20-88)$ & 17 female & $45,79 \pm 7,83^{\circ}$ & $35,93 \pm 6,01$ & $53,75 \pm 8,28^{*}$ & $0.83 \pm 0.73$ & $201.05 \pm 33.41$ \\
\hline \multicolumn{9}{|l|}{ SEX } \\
\hline Male & 30 & $49.6 \pm 20.95$ & & $44,17 \pm 7.17$ & $35,25 \pm 5.90$ & $51,25 \pm 8.56$ & $0.92 \pm 0.60$ & $193.01 \pm 29.48$ \\
\hline Female & 34 & $45.88 \pm 20.65$ & & $43,88 \pm 9.11$ & $34,39 \pm 6.88$ & $50,94 \pm 9.79$ & $0.86 \pm 0.90$ & $205.15 \pm 29.78$ \\
\hline
\end{tabular}

experiments

Values are average $\pm S D$ (range). ${ }^{\circ} p<0.1,{ }^{*} p<0.05 . \% \mathrm{MSO}$, percentage of maximum stimulator output.

(Smith et al., 1999; Wassermann, 2002), as well as stimulus intensities and size of unconditioned MEP amplitude have been discussed as factors that substantially influence measures of cortical excitability and in particular SICI (Kujirai et al., 1993; Hanajima et al., 1998; Sanger et al., 2001; Daskalakis et al., 2002; Ilić et al., 2002; Roshan et al., 2003; Ni et al., 2007; Müller-Dahlhaus et al., 2008; Peurala et al., 2008; Garry and Thomson, 2009; Vucic et al., 2009; Shirota et al., 2010). Therefore, AGE (continuous), SEX (male/female), HEMISPHERE (left/right), size of unconditioned MEP amplitude [single-pulse MEP (spMEP), continuous], as well as all their possible interactions, were added as fixed factors into the basic model. Starting from this first beyond-optimal model, the final model was selected in a series of models by backward selection, i.e., stepwise discarding of all interactions that did not show effects at the $10 \%$ significance level, keeping all main factors in the final model. Furthermore, intercept and spMEP were modeled as random factor on subject level to control for possible effects of unconditioned MEP amplitude size on SICI induction.

In the case of event-related data $\left(\mathrm{SICI}_{\text {move }}\right)$ the main focus was set on SICI modulation during movement preparation. Therefore, the design involved multiple observations (single trials of unconditioned and conditioned MEPs) within six consecutive time zones during the premovement phase, from early phase $\left(t_{-5}\right)$ to late premovement phase $\left(t_{0}\right)$, i.e., close to EMG onset. Slope of SICI modulation was fitted as linear trend (TIMEST) and additionally as second-order polynomial, i.e., quadratic trend $\left(\right.$ TIMEST $^{2}$ ) over the premovement phase from $t_{-5}$ to $t_{0}$. Hence, the basic model comprised of AGE, HEMISPHERE, SEX, spMEP, TIMEST, TIMEST $^{2}$, and all their possible interactions as fixed factors. To account for individual variations and dependencies among responses grouped within subjects, intercepts and slopes (TIMEST, TIMEST ${ }^{2}$ ) were subsequently modeled as random effects on subject level.

To evaluate the possible association between resting-state SICI and

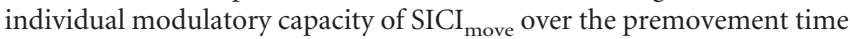
span, prediction models with significant factors only were built from the final resting-state and event-related models. Subject-specific restingstate SICI levels and event-related SICI modulation (slope) were estimated using best linear unbiased predictors (BLUPs), weighted averages of the estimated population-averaged mean response profile and the subject's observed response profile (Henderson, 1975; Pinheiro and Bates, 2009), and entered correlation analyses (Pearson, two-sided).

Behavioral data. All previous analysis steps were replicated for a subgroup of the original sample ( $N=23,9$ female, 11 tested with the dominant right hand, 12 with the left hand) to verify the results obtained so far and to compute BLUPs for the subset of data.

For separate analyses of behavioral outcome parameters (1FT, 2FT, SRT, CRT) the same basic model was used including main factors AGE (continuous), HAND (left/right), SEX (male/female) without any interactions but allowing for a random intercept. Since factor AGE was a relevant main effect for all behavioral outcome it was modeled in the prediction models used to compute BLUPs for each of the behavioral parameters. A correlation analysis was used to examine the relationship between SICI and behavior (Pearson, two-sided).

Data transformation was necessary to meet assumption of the central limit theorem. Natural logarithmic transformation (log) sufficiently assured normal distribution of SICI ${ }_{\text {rest }}$ and SICI $_{\text {move }}$. In the case of the behavioral data natural logarithmic (1FT) and inverse transformation (SRT and CRT: [1/response time in ms]) were applied. Only $2 \mathrm{FT}$ data showed close to normal distribution and required no transformation.

Single trial number was calculated to allow for a data loss of $30 \%$, missing data were not replaced or imputed, neither in outcome nor in independent variable or covariates. Each part of the analysis was on the maximum availabledataset. Data preparation was done using SPSS 19.0 for Macintosh, statistical analyses were performed using the software package R for Statistical Computing version 2.13.1 (2011-07-08, www. r-project.org/) for Mac OS X GUI 1.40-devel Leopard build 64-bit, and package nlme for linear mixed effects modeling (Pinheiro et al., 2011). Results for LME are given as type III sums of squares for sequentially fitted fixed effects $(F, \mathrm{df}, p)$, Wald statistics for marginal parameter estimates ( $t$, df, $p, 95 \% \mathrm{CI})$, as well as variance component estimates for random effects (variance, $\mathrm{SD}$ ).

\section{Results}

\section{Baseline characteristics}

Table 2 depicts baseline characteristics and stimulus intensities for the whole group (ALL, $N=64$ ) and for respective subgroups.

\section{Resting-state SICI}

A total number of 662 observations were included into the analysis, an average of 10.3 trials per subject was acquired. A main effect of AGE $\left(F_{(1,59)}=6.08, p<0.05\right)$ was found (Table 3 ). Parameter estimates indicate that $\mathrm{SICI}_{\text {rest }}$ decreased with every additional year of age, i.e., the average amplitude of the conditioned MEP shows an increase of $\sim 1.6 \%$ (Fig. $1 A$ ). Furthermore, the size of the unconditioned amplitude, spMEP, significantly influenced $\operatorname{SICI}_{\text {rest }}\left(F_{(1,59)}=4.67, p<0.05\right)$. Parameter estimates show that a $10 \%$ increase of spMEP, corresponding to 0.1 increase on the log scale, is associated with a -0.033 decrease of the log transformed conditioned amplitude, i.e., $\sim 3 \%$ increase in $\mathrm{SICI}_{\text {rest }}$. Neither HEMISPHERE nor SEX significantly affected SICI ${ }_{\text {rest }}$ as main effects nor did they significantly modify other effects.

\section{Event-related SICI}

A total number of 3936 observations were included into the analysis, on average 10.3 trials were acquired per subject for each time zone. Results for the final model are given in table

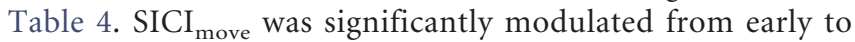
late pre-move time zone (linear trend, TIMEST), $F_{(1,3869)}=$ 38.27, $p<0.0001)$. This means that the conditioned MEP amplitude $\left(\mathrm{SICI}_{\text {move }}\right)$ increased from early to late premovement time zone on average $\sim 35 \%$, corresponding to an increase of 0.301 on the log scale, indicating a release of inhibition ( $\mathrm{SICI}_{\text {move }}$ ) toward movement onset (Fig. $2 \mathrm{~A}$ ).

Furthermore, there was a significant main effect of the quadratic trend $\left(\right.$ TIMEST $\left.^{2}\right)$ on $\operatorname{SICI}_{\text {move }}\left(F_{(1,3869)}=4.78, p<0.05\right)$, 
Table 3. Results of final model for resting-state SICI(log)

\begin{tabular}{|c|c|c|c|c|c|c|c|c|}
\hline \multirow[b]{2}{*}{ BIC 1932.624} & \multicolumn{4}{|l|}{ Wald statistics } & \multicolumn{2}{|c|}{ Approximate $95 \%$ Cl } & \multicolumn{2}{|c|}{ Type III sums of squares test } \\
\hline & Variance component (SD) & Parameter estimates (SE) & $t$-value (df) & $p$-value & Lower & Upper & $F$-value (df) & $p$-value \\
\hline \multicolumn{9}{|l|}{ Random effects } \\
\hline $\begin{array}{l}\text { Intercept | subject } \\
\text { level }\end{array}$ & $0.768(0.876)$ & & & & & & & \\
\hline Residual & $0.796(0.892)$ & & & & & & & \\
\hline \multicolumn{9}{|l|}{ Fixed effects } \\
\hline Intercept & & $2.480(0.359)$ & $6.908(598)$ & $<0.0001$ & 1.775 & 3.186 & $871.058(1,598)$ & $<0.0001$ \\
\hline Sex (male) & & $-0.207(0.236)$ & $-0.879(59)$ & $>0.4$ & -0.679 & 0.264 & $0.593(1,59)$ & $>0.4$ \\
\hline Hemisphere (right) & & $0.288(0.232)$ & $1.241(59)$ & $>0.2$ & -0.176 & 0.753 & $1.217(1,59)$ & $>0.3$ \\
\hline Age (in years) & & $0.016(0.006)$ & $2.796(59)$ & $<0.01$ & 0.005 & 0.028 & $6.083(1,59)$ & $<0.05$ \\
\hline SpMEP (log) & & $-0.329(0.152)$ & $-2.160(59)$ & $<0.05$ & -0.634 & -0.024 & $4.665(1,59)$ & $<0.05$ \\
\hline
\end{tabular}

A

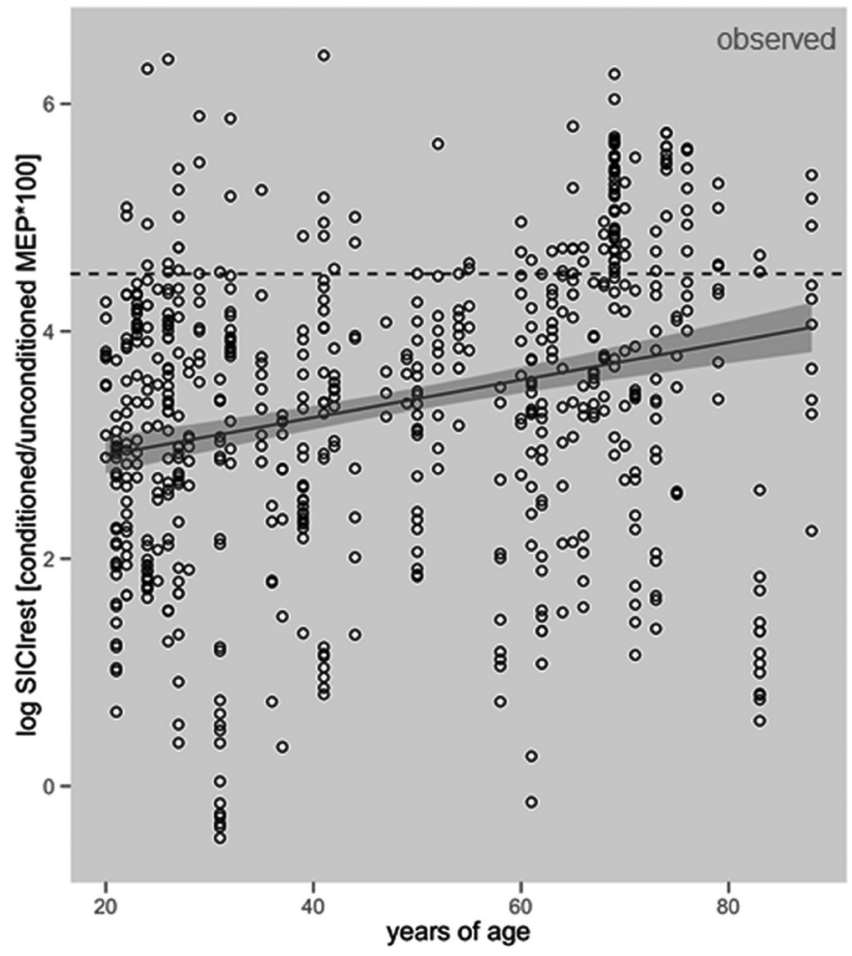

B

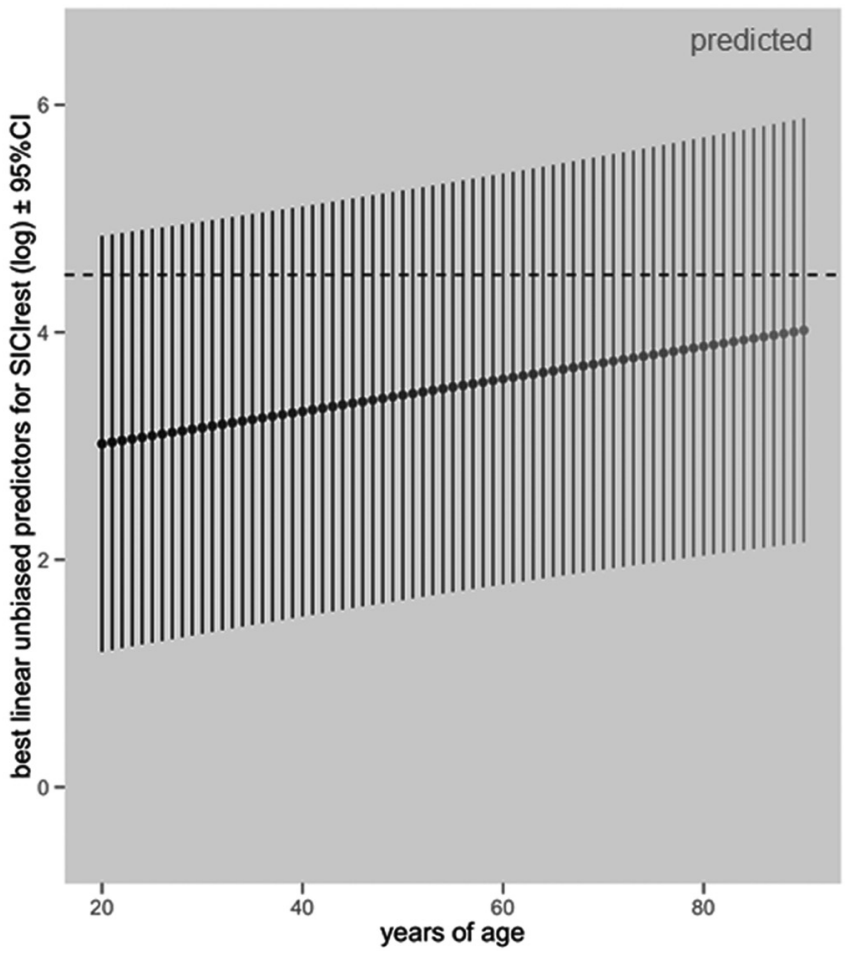

Figure 1. A, Observed resting-state SICI reduction over lifetime (linear regression line $\pm 95 \%$ Cl region). B, Predicted resting-state SICI reduction over lifetime (best linear unbiased predictors \pm $95 \%$ prediction intervals). SICl is presented as conditioned MEP amplitude/unconditioned MEP amplitude $\times 100$ (log transformed). Red dashed horizontal line indicates $100 \%$ SICI (unconditioned $=$ conditioned MEP amplitude on the log scale).

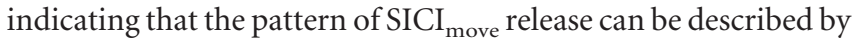
a second-order polynomial approximation ('left curve') from $t_{-5}$ to $t_{0}$ of $1.5 \%$ from early to late pre-movement time. AGE alone did not significantly explain SICI move $_{\text {variation }}(p>0.1)$. A significant AGE $\times$ TIMEST interaction $\left(F_{(1,3869)}=13.43, p<\right.$ 0.001 ) indicated that AGE was a significant effect modulator for pre-move SICI $_{\text {move }}$ modulation. With every additional year of age, the steepness of the linear slope was reduced $\sim-0.3 \%$ (Figs. $2 B, C, 3)$. SICI move was not influenced by factors $\operatorname{SEX}(p>0.7)$, HEMISPHERE ( $p>0.5)$, or any of their interactions.

\section{Relation between resting-state and event-related SICI}

$\mathrm{SICI}_{\text {rest }}$ was strongly associated with $\mathrm{SICI}_{\text {move }}$ modulation $(r=$ $-0.71, p<0.0001$ ), i.e., the more disinhibition at rest, the shallower was the release of inhibition, hence weaker pre-move modulation of $\mathrm{SICI}_{\text {move }}$ when corrected for factor AGE (Fig. 4).

\section{Refitting models for resting-state and event-related SICI in} $N=23$ subgroup

All of the previous results including the correlation between resting-state and event-related SICI could be reproduced for the randomly selected subgroup $(N=23)$ of the original sample.

\section{Behavioral data}

All behavioral tasks showed a significant AGE effect, most pronounced in CRT. Neither SEX nor HAND significantly influenced performance of behavioral tasks (all $p>0.1$ ) with one exception, male subjects showed better performance in 2FT. For all models of behavioral outcome, random intercept significantly improved model fit (all BIC change $>2$ ), proving a relevant within-subjectvariance (Table 5).

AGE significantly influenced performance speed in 1FT $\left(F_{(1,19)}=6.43, p<0.05\right)$. Estimated group-average of $1 \mathrm{FT}$ was 
Table 4. Results of final model for event-related SICI(log)

\begin{tabular}{|c|c|c|c|c|c|c|c|c|}
\hline \multirow[b]{2}{*}{ BIC 11356.16} & \multicolumn{4}{|l|}{ Wald statistics } & \multicolumn{2}{|c|}{ Approximate 95\% Cl } & \multicolumn{2}{|c|}{ Type III sums of squares test } \\
\hline & Variance component (SD) & Parameter estimates (SE) & $t$-value (df) & $p$-value & Lower & Upper & $F$-value (df) & $\overline{p \text {-value }}$ \\
\hline \multicolumn{9}{|l|}{ Random effects } \\
\hline Intercept | subject level & $0.202(0.449)$ & & & & & & & \\
\hline $\begin{array}{l}\text { Linear slope (TIMEST) | } \\
\text { subject level }\end{array}$ & $0.008(0.089)$ & & & & & & & \\
\hline Residual & $0.958(0.979)$ & & & & & & & \\
\hline \multicolumn{9}{|l|}{ Fixed effects } \\
\hline Intercept & & $4.017(0.193)$ & $20.785(3869)$ & $<0.0001$ & 3.639 & 4.396 & $3977.486(1,3869)$ & $<0.0001$ \\
\hline Sex (male) & & $-0.019(0.127)$ & $-0.153(60)$ & $>0.9$ & -0.273 & 0.234 & $0.118(1,60)$ & $>0.7$ \\
\hline Hemisphere (right) & & $0.056(0.126)$ & $0.442(60)$ & $>0.7$ & -0.197 & 0.308 & $0.361(1,60)$ & $>0.6$ \\
\hline Age & & $0.002(0.003)$ & $0.642(60)$ & $>0.5$ & -0.004 & 0.008 & $2.190(1,60)$ & $>0.1$ \\
\hline Linear slope (TIMEST) & & $0.301(0.052)$ & $5.756(3869)$ & $<0.0001$ & 0.198 & 0.4037 & $38.270(1,3869)$ & $<0.0001$ \\
\hline Quadratic slope (TIMEST ${ }^{2}$ ) & & $0.015(0.007)$ & $2.312(3869)$ & $<0.05$ & 0.002 & 0.028 & $4.777(1,3869)$ & $<0.05$ \\
\hline Age*TIMEST & & $-0.003(0.001)$ & $-3.665(3869)$ & $<0.001$ & -0.004 & -0.001 & $13.432(1,3869)$ & $<0.001$ \\
\hline
\end{tabular}

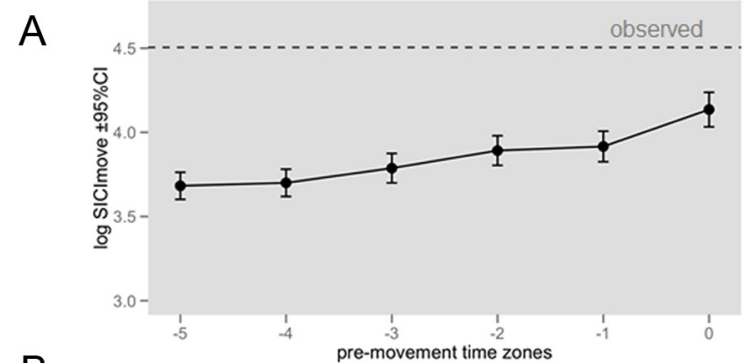

B

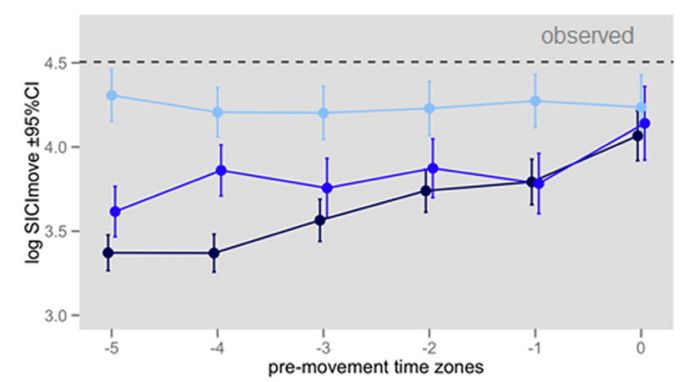

C

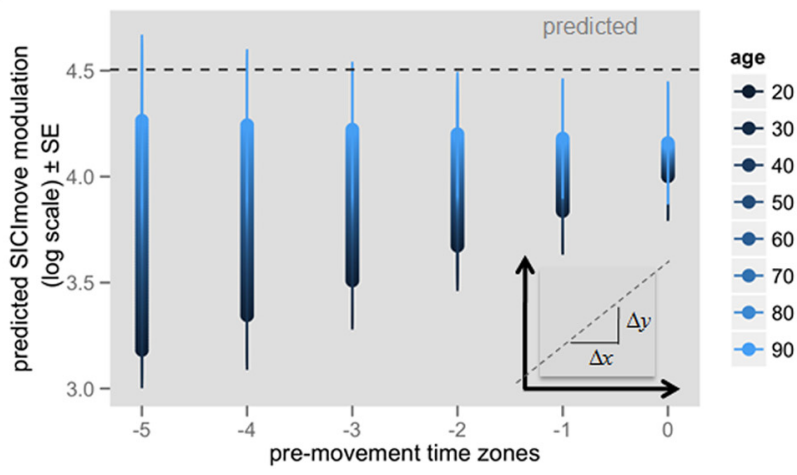

Figure 2. A, Observed $\mathrm{SICl}_{\text {move }}$ modulation from early to late movement preparation (average $\pm 95 \% \mathrm{Cl}$ ) averaged over the whole sample $(N=64)$. Time zones of movement preparation ranged from early $(-5)$, indicating $\sim 35 \%$ of individual reaction time, to late (0), indicating $\sim 95 \%$ of individual reaction time in approximately equal steps. $B, 0 b$ served $\mathrm{SICl}_{\text {move }}$ modulation (average $\pm 95 \% \mathrm{Cl}$ ) depicted for three example age groups: dark blue, young ( $20-40$ years of age); blue, middle-aged ( $40-60$ years of age); light blue, old (60-90 years of age). C, Predicted age-related decrement in $\mathrm{SICI}_{\text {move }}$ modulation (best linear unbiased predictors for linear slope \pm SE) during movement preparation. SICI is presented as conditioned MEP amplitude/unconditioned MEP amplitude $\times 100$ (log transformed). Dashed horizontal line indicates $100 \% \mathrm{SICl}$ (unconditioned = conditioned MEP amplitude on the log scale).
$5.09 \pm 0.08 \mathrm{SE}$ on the log scale, corresponding to an average response speed of $162.4 \mathrm{~ms}$ per key press. With every additional year of age 1 FT slows down $\sim 0.3 \%$ on the log scale, corresponding to $\sim 1 \mathrm{~ms}(p<0.05)$.

Estimated group-average number of $2 \mathrm{FT}$ valid transitions was $55.28 \pm 9.62 \mathrm{SE}$. Factor AGE was marginally significant $\left(F_{(1,19)}=\right.$ $3.54, p=0.07)$, indicating a reduction of valid transitions of $\sim-0.35$ per additional year of age $(p<0.05)$. Factor SEX showed a main effect $\left(F_{(1,19)}=5.89, p>0.05\right)$, with male participants playing on average 17.86 transitions more than females $(p<$ 0.05).

Estimated group-average intercept for inverse transformed SRT (1/SRT) was $3.6^{-3} \pm 2.14^{-4} \mathrm{SE}$, corresponding to a marginal mean SRT of $277.5 \mathrm{~ms}$. Main effect of factor AGE $\left(F_{(1,19)}=\right.$ 5534) showed that every additional year of age was associated with a $-8.28^{-6}$ change in SRT, i.e., an increase of reaction time in SRT of $\sim 0.7 \mathrm{~ms}$ per year of age $(p<0.05)$.

Estimated group-average intercept for inverse transformed CRT (1/CRT) was $2.745^{-3} \pm 1.50^{-4} \mathrm{SE}$, corresponding to a marginal mean CRT of $364.3 \mathrm{~ms}$. AGE significantly influenced $\operatorname{CRT}\left(F_{(1,19)}=39.638, p<0.0001\right)$, showing a $-1.536^{-5} \pm$ $2.41^{-6}$ change, i.e., an increase in reaction time of $\sim 2.6 \mathrm{~ms}$ per additional year of age $(p<0.0001)$.

\section{Correlations between behavior and resting-state SICI}

Analyzing the association between behavioral measures and $\mathrm{SICI}_{\text {rest }}$ revealed a strong correlation between more pronounced SICI $_{\text {rest }}$ with better performance in $2 \mathrm{FT}(r=-0.57, p<0.005)$, and CRT $(-0.59, p<0.003)$, and a moderate correlation with better performance in SRT $(r=-0.42, p<0.05)$, but not with 1FT $(r=0.34, p>0.1)$.

\section{Correlations between behavior and event-related SICI}

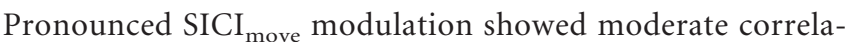
tion with better performance in $2 \mathrm{FT}(r=0.42, p<0.05)$, and 1FT $(r=-0.41, p<0.05)$ and a very strong correlation with better performance in CRT $(r=0.75, p<0.001)$, but not with SRT $(r=0.39, p>0.05)$ (Fig. 5).

\section{Discussion}

The data presented here provide evidence for the existence of a relationship between intracortical inhibition and behavior in terms of dexterous motor performance. It was possible to demonstrate substantial changes in $\mathrm{GABA}_{\mathrm{A}}$-mediated inhibition as defined by a significant decrement in resting-state inhibition measured by means of $\mathrm{SICI}_{\text {rest }}$ with increasing age within a large 
sample presenting a wide range of the adult lifespan. Furthermore, this is the first time to show that event-related modulation of $\mathrm{GABA}_{\mathrm{A}}$ ergic inhibition in terms of a release of inhibition ( $\mathrm{SICI}_{\text {move }}$ ) was drastically reduced in subjects of older age. The level of resting-state inhibition was a significant predictor of eventrelated modulation, i.e., the lower the resting-state inhibition, the weaker was the event-related release of inhibition controlled for factor age. These findings together with the behavioral results of decrements in tasks of graded motor processing load support the hypothesis of the interdependence of diminished $\mathrm{GABA}_{\mathrm{A}}{ }^{-}$ ergic neurotransmission and motor functional decline based on previous data from animal models and computational modeling (Imbrosci and Mittmann, 2011).

Previous studies examining age-effects on $\mathrm{GABA}_{\mathrm{A}}$ ergic inhibitory neurotransmission using dpTMS mainly focused on resting-state analyses (Peinemann et al., 2001; Kossev et al., 2002; Wassermann, 2002; Oliviero et al., 2006; Smith et al., 2009; McGinley et al., 2010), however controversial findings allow no clear interpretation at this point in time. Moreover, while only few studies examined event-related SICI (Smyth et al., 2010) even less is known about the influence of factor age on event-related modulation of inhibition in contrast to resting-state levels (Fujiyama et al., 2011, 2012), their interactions and respective effects on dexterous manual motor behavior (McGinley et al., 2010; Marneweck et al., 2011).

\section{Resting-state inhibition defines general} speed of motor response generation

Stronger resting-state inhibition was generally associated with better motor performance. Bearing in mind that the $\mathrm{GABA}_{\mathrm{A}}$ ergic intracortical inhibitory system is thought to fine-tune and shape neuronal firing (Farrant and Nusser, 2005), it is suggested that the prevailing disinhibition of the extent found in subjects of old age might negatively impact on the precision and synchronization of action potential timing of the motorcortical excitatory neurons as it has been hypothesized to occur in several neocortical areas during aging (Cobb et al., 1995; Borg-Graham et al., 1998; Galarreta and Hestrin, 1998; Shu et al., 2003; 100Wehr and Zador, 2003; Buzsáki and Draguhn, 2004; Bacci and Huguenard, 2006; Haider et al., 2006; Fuchs et al., 2007; Cardin et al., 2009; Haider and McCormick, 2009; Sohal et al., 2009; Manseau et al., 2010). Hence, motor processing is impaired, i.e., the phase of response generation is slowed down. This fits well with the previous finding of a specific slowing of response generation at an advanced age (Yordanova et al., 2004; Falkenstein et al., 2006; Roggeveen et al., 2007), contrasting the earlier idea of a general unspecific decline

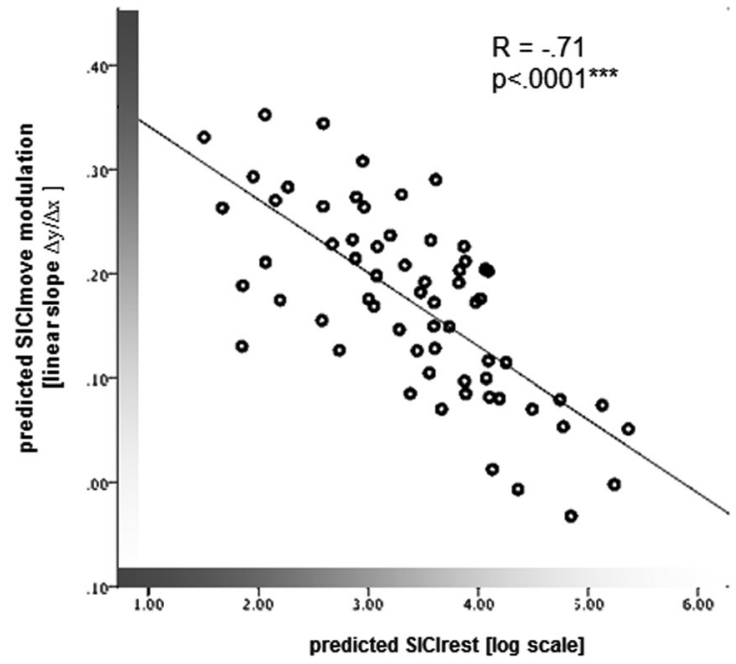

weak

inhibition disinhibition

Figure 4. Association between resting-state $\mathrm{SICl}$ level and $\mathrm{SICl}_{\text {move }}$ modulation during movement preparation. The more disinhibited at rest, the weaker the modulation of event-related inhibition.

in central processing with increasing age (Crossley and Hiscock, 1992; Reuter-Lorenz, 2002).

\section{Event-related inhibition is associated with complex motor performance}

Stronger event-related modulation of inhibition, however, was correlated with better performance in more complex manual motor tasks. On the one hand, alternating two-finger tapping and choice reaction time tasks both necessitate the precisely timed coordination of inhibition and disinhibition/activation of cortical representations of effector muscles. As in all of the motor tasks analyzed here, the FDI is a main effector muscle and as the electrophysiological measures were recorded within the cortical representation of that muscle (FDI), it is very likely that the changes demonstrated here in $\mathrm{GABA}_{\mathrm{A}}$ ergic inhibition are specific to the 
Table 5. Results for all models of behavioral outcome

\begin{tabular}{|c|c|c|c|c|c|c|c|c|c|}
\hline \multirow[b]{3}{*}{ Behavioral outcome } & \multirow[b]{3}{*}{ Final model $N=23$} & \multicolumn{4}{|l|}{ Wald statistics } & \multirow{2}{*}{\multicolumn{2}{|c|}{ Approximate 95\% Cl }} & \multirow{2}{*}{\multicolumn{2}{|c|}{ Type III sums of squares test }} \\
\hline & & \multirow{2}{*}{$\begin{array}{l}\text { Variance component } \\
\text { (SD) }\end{array}$} & \multirow{2}{*}{$\begin{array}{l}\text { Parameter estimates } \\
\text { (SE) }\end{array}$} & \multirow[b]{2}{*}{$t(\mathrm{df})$} & \multirow[b]{2}{*}{$p$} & & & & \\
\hline & & & & & & Lower & Upper & $F(\mathrm{df})$ & $p$ \\
\hline \multirow{8}{*}{ 1FT $(\log )$ BIC -4915.744} & Random effects & & & & & & & & \\
\hline & Intercept | subject level & $0.017(0.13)$ & & & & & & & \\
\hline & Residual & $0.025(0.16)$ & & & & & & & \\
\hline & Fixed effects & & & & & & & & \\
\hline & Intercept & & $5.094(0.08)$ & $61.716(3227)$ & $<0.0001$ & 4.916 & 5.252 & $37860.15(1,3385)$ & $<0.0001$ \\
\hline & Age (in years) & & $0.003(0.001)$ & $2.498(19)$ & $<0.05$ & 0.001 & 0.007 & $6.43(1,19)$ & $<0.05$ \\
\hline & Sex (male) & & $0.071(0.06)$ & 1.289 (19) & $>0.2$ & -0.038 & 0.203 & $2.93(1,19)$ & $>0.1$ \\
\hline & Hand used (right) & & $-0.075(0.05)$ & $-1.396(19)$ & $>0.2$ & -0.175 & 0.059 & $1.09(1,19)$ & $>0.3$ \\
\hline \multicolumn{10}{|l|}{$\begin{array}{l}\text { 2FT (number of valid } \\
\text { transitions) }\end{array}$} \\
\hline \multirow[t]{8}{*}{ BIC 487.0502 } & Random effects & & & & & & & & \\
\hline & Intercept | subject level & $235.027(15.33)$ & & & & & & & \\
\hline & Residual & 17.797 (4.22) & & & & & & & \\
\hline & Fixed effects & & & & & & & & \\
\hline & Intercept & & $55.282(9.62)$ & $5.750(46)$ & $<0.0001$ & 35.927 & 74.637 & $194.162(1,46)$ & $<0.0001$ \\
\hline & Age (in years) & & $-0.348(0.16)$ & $-2.125(19)$ & $<0.05$ & -0.691 & -0.005 & $3.535(1,19)$ & $<0.07$ \\
\hline & Sex (male) & & $17.860(6.86)$ & $2.604(19)$ & $<0.05$ & 3.503 & 32.216 & $5.886(1,19)$ & $<0.05$ \\
\hline & Hand used (right) & & $-7.0472(6.66)$ & $-1.057(19)$ & $>0.3$ & -20.996 & 6.901 & $1.118(1,19)$ & $>0.3$ \\
\hline \multicolumn{10}{|l|}{ SRT (1/ms) BIC } \\
\hline \multirow[t]{8}{*}{-29363.68} & Random effects & & & & & & & & \\
\hline & Intercept | subject level & $1.0317^{-7}\left(0.3^{-4}\right)$ & & & & & & & \\
\hline & Residual & $2.797^{-7}\left(0.5^{-4}\right)$ & & & & & & & \\
\hline & Fixed effects & & & & & & & & \\
\hline & Intercept & & $3.604^{-3}\left(2.14^{-4}\right)$ & $16.821(2390)$ & $<0.0001$ & $3.184^{-3}$ & $4.023^{-3}$ & $2212.711(1,2390)$ & $<0.0001$ \\
\hline & Age (in years) & & $-8.280^{-6}\left(3.43^{-6}\right)$ & $-2.412(19)$ & $<0.05$ & $-1.547^{-5}$ & $-1.095^{-6}$ & $5.534(1,19)$ & $<0.05$ \\
\hline & Sex (male) & & $-6.298^{-5}\left(1.44^{-4}\right)$ & $-0.438(19)$ & $>0.7$ & $-3.638^{-4}$ & $2.378^{-4}$ & $0.314(1,19)$ & $>0.6$ \\
\hline & Hand used (right) & & $6.525^{-5}\left(1.40^{-4}\right)$ & $0.467(19)$ & $>0.7$ & $-2.270^{-4}$ & $3.575^{-4}$ & $0.220(1,19)$ & $>0.7$ \\
\hline \multicolumn{10}{|l|}{ CRT (1/ms) BIC } \\
\hline \multirow[t]{8}{*}{-26815.77} & Random effects & & & & & & & & \\
\hline & Intercept | subject level & $5.090^{-8}\left(2.26^{-5}\right)$ & & & & & & & \\
\hline & Residual & $9.072^{-8}\left(3.01^{-5}\right)$ & & & & & & & \\
\hline & Fixed effects & & & & & & & & \\
\hline & Intercept & & $2.745^{-3}\left(1.50^{-4}\right)$ & $18.282(1997)$ & $<0.0001$ & $2.450^{-3}$ & $3.039^{-3}$ & $1573.408(1,1997)$ & $<0.0001$ \\
\hline & Age (in years) & & $-1.536^{-5}\left(2.41^{-6}\right)$ & $-6.386(19)$ & $<0.0001$ & $-2.040^{-5}$ & $-1.033^{-5}$ & $39.638(1,19)$ & $<0.0001$ \\
\hline & Sex (male) & & $-1.368^{-4}\left(1.01^{-4}\right)$ & $-1.359(19)$ & $>0.2$ & $-3.476^{-4}$ & $7.396^{-5}$ & $1.598(1,19)$ & $>0.2$ \\
\hline & Hand used (right) & & $-5.480^{-5}\left(9.78^{-5}\right)$ & $-0.560(19)$ & $>0.6$ & $-2.596^{-4}$ & $1.500^{-4}$ & $0.314(1,19)$ & $>0.6$ \\
\hline
\end{tabular}

motorcortical representation of the FDI and not due to rather unspecific mechanisms such as surround inhibition of other muscle representations (Beck and Hallett, 2010).

On the other hand, tasks with higher premotor processing load, i.e., with a warned foreperiod like CRT in the present experiment, have been hypothesized to be particularly susceptible to age-related decline of intracortical inhibitory neurotransmission (Sinclair and Hammond, 2008; Tandonnet et al., 2010; Fujiyama et al., 2012). During this foreperiod it is assumed that the warning signal induces a priming of the motor representations and additionally precluding premature response execution (Duqué and Ivry, 2009; van de Laar et al., 2012). CRT performance was found to strongly correlate with $\mathrm{SICI}_{\text {move }}$ modulation, which would support the hypothesis of the particular importance of $\mathrm{GABA}_{\mathrm{A}} \mathrm{er}$ gic inhibition for premotor processing.

In the CRT the externally triggered response-selection process poses an additional cognitive demand. In the case of 2FT two competing motor responses need to be internally coordinated. It is conceivable that this process requires more cognitive load in addition to more complex motor processing. One might hypothesize that event-related modulation of inhibition indicates the system's efficiency in synaptic integration, which is significantly reduced when the $\mathrm{GABA}_{\mathrm{A}}$ ergic neurotransmission is weakened (Farrant and Nusser, 2005). Another explanation might therefore be that higher cognitive processing load requires in general more extensive processing and integration of multiple information before or at the same time as motor response generation depending on intracortical $\mathrm{GABA}_{\mathrm{A}}$ ergic inhibition.

Finally, a summation of several of these effects, which are susceptible to declining inhibitory neurotransmission, is also a reasonable explanation of the current findings.

\section{Prevailing disinhibition-compensatory mechanism or loss of functionality?}

The question remains whether the observed reduction in motorcortical inhibition reflects a mechanism to enhance neuroplasticity as to adapt to the functional constraints of increasing age or whether it marks an age-related disintegrity of the motor system causing functional decline.

Reduced GABA levels during development promote enhanced plastic capacity of nervous system maturation (Meng et al., 2004; Walther et al., 2009; Pinto et al., 2010). During the process of aging the nervous system needs to perform substantial adaptations to reduced peripheral input (Coq and Xerri, 2000; Godde et al., 2002) as well as diminished muscular-skeletal functioning (Galganski et al., 1993; Eisen et al., 1996; Doherty and Brown, 1997; Desrosiers et al., 1999; Krampe, 2002; Enoka et al., 2003) to maintain integrity of behavior. It is therefore tempting to speculate that the observed reduction in $\mathrm{GABA}_{\mathrm{A}}$-mediated resting-state inhibition possibly reflects one underlying mecha- 


\section{low motor processing load}

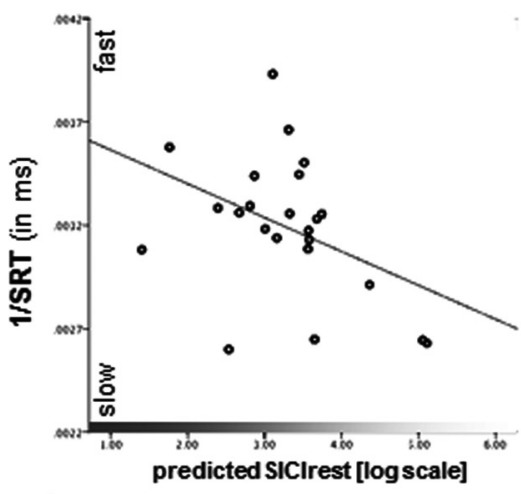

resting-state $\mathrm{SICl}$ level

\section{high motor processing load}

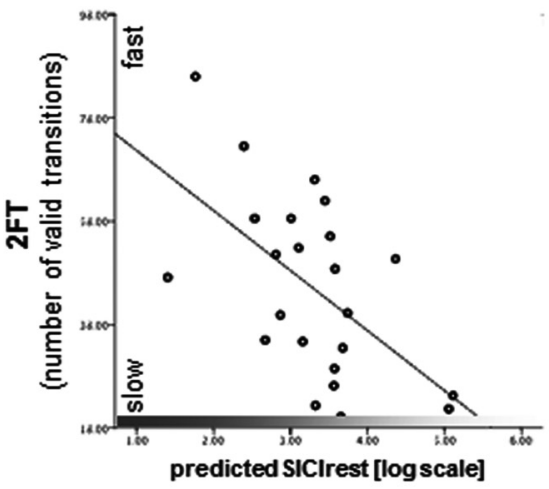

$\mathrm{R}=-.57$

$\mathrm{p}<.005^{\star \star}$

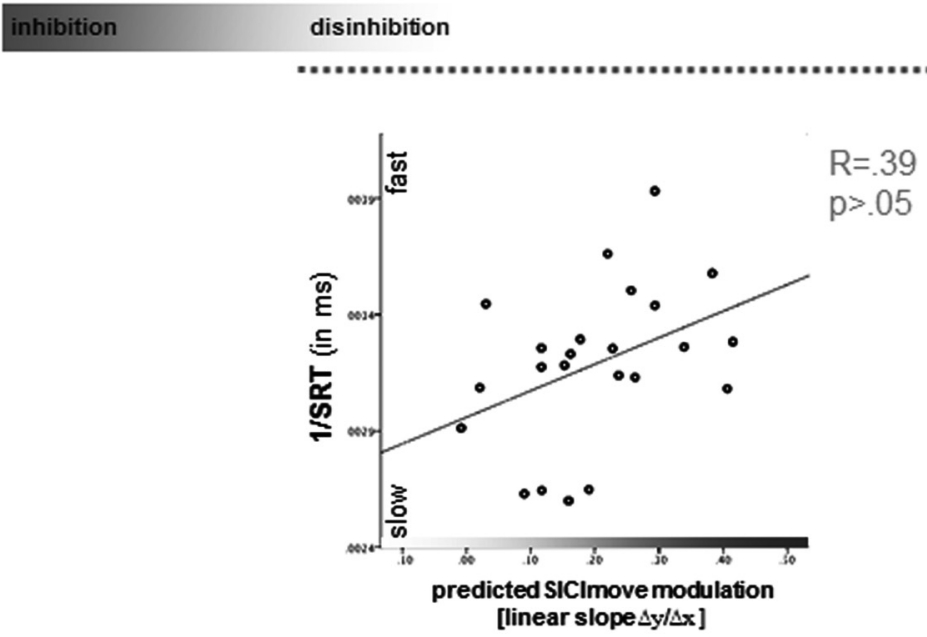

event-related SICI modulation

weak

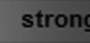

Figure 5. Correlations between behavioral parameters and resting-state inhibition (top row), and event-related modulation of inhibition (bottom row). Overall, stronger resting-state inhibition correlated with overall better manual performance. Stronger event-related modulation of inhibition, expressed as linear slope, was associated with better performance in tasks with higher dexterous demands, i.e., higher motor processing load such as 2FT and CRT.

nism aimed at enhancing neuronal plasticity to adapt to the multimodal constraints of increasing age (Caspary et al., 1999; Grachev et al., 2001; Hoekzema et al., 2012). From this perspective the current observations could be interpreted according to the concept of homeostatic disinhibition compensating for an overall reduced excitatory drive, which has been proposed as a mechanism to recruit additional cognitive reserve during healthy aging (Gleichmann et al., 2011).

However, the current findings give rise to the assumption that these adaptations happen at least in parts at the expense of a loss of modulatory capacity of $\mathrm{GABA}_{\mathrm{A}}$ ergic neurotransmission. Particularly, the loss of rapid event-related SICI modulation could be interpreted as an indicator of a transition between compensation and loss of function. When resting-state inhibition is weak, the inhibitory motorcortical system in aged subjects might already be beyond the limits of modulatory capacity with a subsequent loss of functionality, leading to reduced precision in different stages of motor processing and loss of efficiency of synaptic integration. The result could be a loss of speed and dexterity as seen in the age-related decline in performance in independent finger move- ments tested by the present experiments. We suggest that restingstate SICI could reflect to some extent an overall level of inhibitory tone while event-related modulation of SICI rather reflects the capacity for fast synaptic phasic inhibition, both underlying $\mathrm{GABA}_{\mathrm{A}}$-mediated intracortical circuits.

\section{Limitations}

In accordance with previous data (Sanger et al., 2001; Daskalakis et al., 2002; Ilić et al., 2002; Garry and Thomson, 2009), restingstate spMEP was found to significantly influence resting-state SICI induction, i.e., larger spMEP amplitudes leading to stronger inhibition at rest, even though the strategy in this experiment was to adjust for $1 \mathrm{mV}$ spMEP amplitudes. However, no effect of spMEP was found for event-related SICI modulation. Although several previous studies indicated that factors hemisphere (Rossini et al., 1992; Sale and Semmler, 2005; Smith et al., 2009) and sex (Smith et al., 1999; Wassermann, 2002) potentially influence SICI and possibly interact with age-effects, these results could not be confirmed here. Moreover, previous TMS studies examining effects of aging show considerable variation regarding 
important methodological aspects; these are (1) age group selection (on average younger participants and narrower age range), (2) stimulus parameters (intensities, interstimulus intervals), (3) technical equipment (coil shape, stimulus waveform), and (4) target muscle selection (Peinemann et al., 2001; Kossev et al., 2002; Wassermann, 2002; Oliviero et al., 2006; Smith et al., 2009; McGinley et al., 2010; Marneweck et al., 2011).

\section{Conclusion}

Resting-state $\mathrm{GABA}_{\mathrm{A}}$-mediated inhibition was found to be a significant predictor for the capacity of event-related modulation both of which clearly correlating with dexterous motor performance. Therefore, a causal interdependence might be suggested, which needs to be further verified in future work particularly regarding directionality. Of special interest would be to define the turning point at which compensation leads to loss of functionality. It would be interesting if short-term perturbations of the inhibitory tone are possible and whether they could provoke changes in modulatory capacity and at the same time lead to alterations of motor behavior.

\section{References}

Baroncelli L, Braschi C, Spolidoro M, Begenisic T, Maffei L, Sale A (2011) Brain plasticity and disease: a matter of inhibition. Neural Plast 2011: 286073. Medline

Bacci A, Huguenard JR (2006) Enhancement of spike-timing precision by autaptic transmission in neocortical inhibitory interneurons. Neuron 49: 119-130. CrossRef Medline

Beck S, Hallett M (2010) Surround inhibition is modulated by task difficulty. Clin Neurophysiol 121:98-103. CrossRef Medline

Borg-Graham LJ, Monier C, Frégnac Y (1998) Visual input evokes transient and strong shunting inhibition in visual cortical neurons. Nature 393: 369-373. CrossRef Medline

Brown H, Prescott R (2006) Applied mixed models in medicine. West Sussex, UK: Wiley.

Buzsáki G, Draguhn A (2004) Neuronal oscillations in cortical networks. Science 304:1926-1929. CrossRef Medline

Byblow WD, Stinear CM (2006) Modulation of short-latency intracortical inhibition in human primary motor cortex during synchronised versus syncopated finger movements. Exp Brain Res 168:287-293. CrossRef Medline

Cardin JA, Carlén M, Meletis K, Knoblich U, Zhang F, Deisseroth K, Tsai LH, Moore CI (2009) Driving fast-spiking cells induces gamma rhythm and controls sensory responses. Nature 459:663-667. CrossRef Medline

Caspary DM, Holder TM, Hughes LF, Milbrandt JC, McKernan RM, Naritoku DK (1999) Age-related changes in GABA(A) receptor subunit composition and function in rat auditory system. Neuroscience 93:307312. CrossRef Medline

Chagnac-Amitai Y, Connors BW (1989) Horizontal spread of synchronized activity in neocortex and its control by GABA-mediated inhibition. J Neurophysiol 61:747-758. Medline

Cobb SR, Buhl EH, Halasy K, Paulsen O, Somogyi P (1995) Synchronization of neuronal activity in hippocampus by individual GABAergic interneurons. Nature 378:75-78. CrossRef Medline

Coq JO, Xerri C (2000) Age-related alteration of the forepaw representation in the rat primary somatosensory cortex. Neuroscience 99:403-411. CrossRef Medline

Crossley M, Hiscock M (1992) Age-related differences in concurrent-task performance of normal adults: evidence for a decline in processing resources. Psychol Aging 7:499-506. CrossRef Medline

Daskalakis ZJ, Christensen BK, Fitzgerald PB, Roshan L, Chen R (2002) The mechanisms of interhemispheric inhibition in the human motor cortex. J Physiol 543:317-326. CrossRef Medline

David-Jürgens M, Dinse HR (2010) Effects of aging on paired-pulse behavior of rat somatosensory cortical neurons. Cereb Cortex 20:1208-1216. CrossRef Medline

Desrosiers J, Hébert R, Bravo G, Rochette A (1999) Age-related changes in upper extremity performance of elderly people: a longitudinal study. Exp Gerontol 34:393-405. CrossRef Medline
Di Lazzaro V, Oliviero A, Profice P, Pennisi MA, Di Giovanni S, Zito G, Tonali P, Rothwell JC (2000) Muscarinic receptor blockade has differential effects on the excitability of intracortical circuits in the human motor cortex. Exp Brain Res 135:455-461. CrossRef Medline

Di Lazzaro V, Oliviero A, Pilato F, Saturno E, Dileone M, Marra C, Ghirlanda S, Ranieri F, Gainotti G, Tonali P (2005a) Neurophysiological predictors of long term response to AChE inhibitors in AD patients. J Neurol Neurosurg Psychiatry 76:1064-1069. CrossRef Medline

Di Lazzaro V, Oliviero A, Saturno E, Dileone M, Pilato F, Nardone R, Ranieri F, Musumeci G, Fiorilla T, Tonali P (2005b) Effects of lorazepam on short latency afferent inhibition and short latency intracortical inhibition in humans. J Physiol 564:661-668. CrossRef Medline

Doherty TJ, Brown WF (1997) Age-related changes in the twitch contractile properties of human thenar motor units. J Appl Physiol 82:93-101. Medline

Duqué J, Ivry RB (2009) Role of corticospinal suppression during motor preparation. Cereb Cortex 19:2013-2024. CrossRef Medline

Eisen A, Entezari-Taher M, Stewart H (1996) Cortical projections to spinal motoneurons: changes with aging and amyotrophic lateral sclerosis. Neurology 46:1396-1404. CrossRef Medline

Enoka RM, Christou EA, Hunter SK, Kornatz KW, Semmler JG, Taylor AM, Tracy BL (2003) Mechanisms that contribute to differences in motor performance between young and old adults. J Electromyogr Kinesiol 13: 1-12. CrossRef Medline

Falkenstein M, Yordanova J, Kolev V (2006) Effects of aging on slowing of motor-response generation. Int J Psychophysiol 59:22-29. CrossRef Medline

Farrant M, Nusser Z (2005) Variations on an inhibitory theme: phasic and tonic activation of GABA(A) receptors. Nat Rev Neurosci 6:215-229. CrossRef Medline

Fisher RJ, Nakamura Y, Bestmann S, Rothwell JC, Bostock H (2002) Two phases of intracortical inhibition revealed by transcranial magnetic threshold tracking. Exp Brain Res 143:240-248. CrossRef Medline

Floyer-Lea A, Wylezinska M, Kincses T, Matthews PM (2006) Rapid modulation of GABA concentration in human sensorimotor cortex during motor learning. J Neurophysiol 95:1639-1644. CrossRef Medline

Fuchs EC, Zivkovic AR, Cunningham MO, Middleton S, Lebeau FE, Bannerman DM, Rozov A, Whittington MA, Traub RD, Rawlins JN, Monyer H (2007) Recruitment of parvalbumin-positive interneurons determines hippocampal function and associated behavior. Neuron 53:591-604. CrossRef Medline

Fujiyama H, Tandonnet C, Summers JJ (2011) Age-related differences in corticospinal excitability during a Go/NoGo task. Psychophysiology 48: 1448-1455. CrossRef Medline

Fujiyama H, Hinder MR, Schmidt MW, Tandonnet C, Garry MI, Summers JJ (2012) Age-related differences in corticomotor excitability and inhibitory processes during a visuomotor RT task. J Cogn Neurosci 24:12531263. CrossRef Medline

Galarreta M, Hestrin S (1998) Frequency-dependent synaptic depression and the balance of excitation and inhibition in the neocortex. Nat Neurosci 1:587-594. CrossRef Medline

Galganski ME, Fuglevand AJ, Enoka RM (1993) Reduced control of motor output in a human hand muscle of elderly subjects during submaximal contractions. J Neurophysiol 69:2108-2115. Medline

Garry MI, Thomson RH (2009) The effect of test TMS intensity on shortinterval intracortical inhibition in different excitability states. Exp Brain Res 193:267-274. CrossRef Medline

Gleichmann M, Chow VW, Mattson MP (2011) Homeostatic disinhibition in the aging brain and Alzheimer's disease. J Alzheimers Dis 24:15-24. Medline

Godde B, Berkefeld T, David-Jürgens M, Dinse HR (2002) Age-related changes in primary somatosensory cortex of rats: evidence for parallel degenerative and plastic-adaptive processes. Neurosci Biobehav Rev 26: 743-752. CrossRef Medline

Grachev ID, Swarnkar A, Szeverenyi NM, Ramachandran TS, Apkarian AV (2001) Aging alters the multichemical networking profile of the human brain: an in vivo (1)H-MRS study of young versus middle-aged subjects. J Neurochem 77:292-303. CrossRef Medline

Haider B, McCormick DA (2009) Rapid neocortical dynamics: cellular and network mechanisms. Neuron 62:171-189. CrossRef Medline

Haider B, Duque A, Hasenstaub AR, McCormick DA (2006) Neocortical 
network activity in vivo is generated through a dynamic balance of excitation and inhibition. J Neurosci 26:4535-4545. CrossRef Medline

Hanajima R, Ugawa Y, Terao Y, Sakai K, Furubayashi T, Machii K, Kanazawa I (1998) Paired-pulse magnetic stimulation of the human motor cortex: differences among I waves. J Physiol 509:607-618. CrossRef Medline

Heise KF, Steven B, Liuzzi G, Thomalla G, Jonas M, Müller-Vahl K, Sauseng P, Münchau A, Gerloff C, Hummel FC (2010) Altered modulation of intracortical excitability during movement preparation in Gilles de la Tourette syndrome. Brain 133:580-590. CrossRef Medline

Henderson CR (1975) Best linear unbiased estimation and prediction under a selection model. Biometrics 31:423-447. CrossRef Medline

Hoekzema E, Rojas S, Herance R, Pareto D, Abad S, Jiménez X, Figueiras FP, Popota F, Ruiz A, Flotats N, Fernández FJ, Rocha M, Rovira M, Víctor VM, Gispert JD (2012) In vivo molecular imaging of the GABA/benzodiazepine receptor complex in the aged rat brain. Neurobiol Aging 33: 1457-1465. CrossRef Medline

Hua T, Kao C, Sun Q, Li X, Zhou Y (2008) Decreased proportion of GABA neurons accompanies age-related degradation of neuronal function in cat striate cortex. Brain Res Bull 75:119-125. CrossRef Medline

Hummel FC, Steven B, Hoppe J, Heise K, Thomalla G, Cohen LG, Gerloff C (2009) Deficient intracortical inhibition (SICI) during movement preparation after chronic stroke. Neurology 72:1766-1772. CrossRef Medline

Hummel FC, Heise K, Celnik P, Floel A, Gerloff C, Cohen LG (2010) Facilitating skilled right hand motor function in older subjects by anodal polarization over the left primary motor cortex. Neurobiol Aging 31:2160-2168. CrossRef Medline

Ilić TV, Meintzschel F, Cleff U, Ruge D, Kessler KR, Ziemann U (2002) Short-interval paired-pulse inhibition and facilitation of human motor cortex: the dimension of stimulus intensity. J Physiol 545:153-167. CrossRef Medline

Imbrosci B, Mittmann T (2011) Functional consequences of the disturbances in the GABA-mediated inhibition induced by injuries in the cerebral cortex. Neural Plast 2011:614329. Medline

Kossev AR, Schrader C, Däuper J, Dengler R, Rollnik JD (2002) Increased intracortical inhibition in middle-aged humans; a study using pairedpulse transcranial magnetic stimulation. Neurosci Lett 333:83-86. CrossRef Medline

Krampe RT (2002) Aging, expertise and fine motor movement. Neurosci Biobehav Rev 26:769-776. CrossRef Medline

Kujirai T, Caramia MD, Rothwell JC, Day BL, Thompson PD, Ferbert A, Wroe S, Asselman P, Marsden CD (1993) Corticocortical inhibition in human motor cortex. J Physiol 471:501-519. Medline

Le Roux N, Amar M, Moreau A, Baux G, Fossier P (2008) Impaired GABAergic transmission disrupts normal homeostatic plasticity in rat cortical networks. Eur J Neurosci 27:3244-3256. CrossRef Medline

Leventhal AG, Wang Y, Pu M, Zhou Y, Ma Y (2003) GABA and its agonists improved visual cortical function in senescent monkeys. Science 300:812815. CrossRef Medline

Ling LL, Hughes LF, Caspary DM (2005) Age-related loss of the GABA synthetic enzyme glutamic acid decarboxylase in rat primary auditory cortex. Neuroscience 132:1103-1113. CrossRef Medline

Manseau F, Marinelli S, Méndez P, Schwaller B, Prince DA, Huguenard JR, Bacci A (2010) Desynchronization of neocortical networks by asynchronous release of GABA at autaptic and synaptic contacts from fast-spiking interneurons. PLoS Biol 8:e1000492. CrossRef Medline

Marneweck M, Loftus A, Hammond G (2011) Short-interval intracortical inhibition and manual dexterity in healthy aging. Neurosci Res 70:408414. CrossRef Medline

McGinley M, Hoffman RL, Russ DW, Thomas JS, Clark BC (2010) Older adults exhibit more intracortical inhibition and less intracortical facilitation than young adults. Exp Gerontol 45:671-678. CrossRef Medline

Meng Z, Li Q, Martin JH (2004) The transition from development to motor control function in the corticospinal system. J Neurosci 24:605-614. CrossRef Medline

Miura K, Tsubo Y, Okada M, Fukai T (2007) Balanced excitatory and inhibitory inputs to cortical neurons decouple firing irregularity from rate modulations. J Neurosci 27:13802-13812. CrossRef Medline

Müller-Dahlhaus JF, Liu Y, Ziemann U (2008) Inhibitory circuits and the nature of their interactions in the human motor cortex a pharmacological TMS study. J Physiol 586:495-514. Medline

Ni Z, Gunraj CA, Chen R (2007) Short interval intracortical inhibition and facilitation during the silent period in human. J Physiol 583:971-982. CrossRef

Oldfield RC (1971) The assessment and analysis of handedness: the Edinburgh inventory. Neuropsychologia 9:97-113. CrossRef Medline

Oliviero A, Profice P, Tonali PA, Pilato F, Saturno E, Dileone M, Ranieri F, Di Lazzaro V (2006) Effects of aging on motor cortex excitability. Neurosci Res 55:74-77. CrossRef Medline

Peinemann A, Lehner C, Conrad B, Siebner HR (2001) Age-related decrease in paired-pulse intracortical inhibition in the human primary motor cortex. Neurosci Lett 313:33-36. CrossRef Medline

Peurala SH, Müller-Dahlhaus JF, Arai N, Ziemann U (2008) Interference of short-interval intracortical inhibition (SICI) and short-interval intracortical facilitation (SICF). Clin Neurophysiol 119:2291-2297. CrossRef Medline

Pinheiro JC, Bates DM (2009) Mixed-effects models in S and S-PLUS. New York: Springer.

Pinheiro J, Bates D, DebRoy S, Sarkar D, Team RDC (2011) nlme: linear and nonlinear mixed effects models. In: R package, 3.1-102 Edition.

Pinto JGA, Hornby KR, Jones DG, Murphy KM (2010) Developmental changes in GABAergic mechanisms in human visual cortex across the lifespan. Front Cell Neurosci 4:16. Medline

Reuter-Lorenz P (2002) New visions of the aging mind and brain. Trends Cogn Sci 6:394. CrossRef Medline

Reynolds C, Ashby P (1999) Inhibition in the human motor cortex is reduced just before a voluntary contraction. Neurology 53:730-735. CrossRef Medline

Roggeveen AB, Prime DJ, Ward LM (2007) Lateralized readiness potentials reveal motor slowing in the aging brain. J Gerontol B Psychol Sci Soc Sci 62:P78-P84. CrossRef Medline

Roshan L, Paradiso GO, Chen R (2003) Two phases of short-interval intracortical inhibition. Exp Brain Res 151:330-337. CrossRef Medline

Rossi S, Hallett M, Rossini PM, Pascual-Leone A (2009) Safety, ethical considerations, and application guidelines for the use of transcranial magnetic stimulation in clinical practice and research. Clin Neurophysiol 120:2008-2039. CrossRef Medline

Rossini PM, Desiato MT, Caramia MD (1992) Age-related changes of motor evoked potentials in healthy humans: non-invasive evaluation of central and peripheral motor tracts excitability and conductivity. Brain Res 593:14-19. CrossRef Medline

Sale MV, Semmler JG (2005) Age-related differences in corticospinal control during functional isometric contractions in left and right hands. J Appl Physiol 99:1483-1493. CrossRef Medline

Sanger TD, Garg RR, Chen R (2001) Interactions between two different inhibitory systems in the human motor cortex. J Physiol 530:307-317. CrossRef Medline

Schmidt S, Redecker C, Bruehl C, Witte OW (2010) Age-related decline of functional inhibition in rat cortex. Neurobiol Aging 31:504-511. CrossRef Medline

Semyanov A, Walker MC, Kullmann DM (2003) GABA uptake regulates cortical excitability via cell type-specific tonic inhibition. Nat Neurosci 6:484-490. Medline

Semyanov A, Walker MC, Kullmann DM, Silver RA (2004) Tonically active GABA A receptors: modulating gain and maintaining the tone. Trends Neurosci 27:262-269. CrossRef Medline

Shirota Y, Hamada M, Terao Y, Matsumoto H, Ohminami S, Furubayashi T, Nakatani-Enomoto S, Ugawa Y, Hanajima R (2010) Influence of shortinterval intracortical inhibition on short-interval intracortical facilitation in human primary motor cortex. Journal of Neurophysiology 104:13821391. CrossRef Medline

Shu Y, Hasenstaub A, McCormick DA (2003) Turning on and off recurrent balanced cortical activity. Nature 423:288-293. CrossRef Medline

Sinclair C, Hammond GR (2008) Reduced intracortical inhibition during the foreperiod of a warned reaction time task. Exp Brain Res 186:385-392. CrossRef Medline

Smith AE, Ridding MC, Higgins RD, Wittert GA, Pitcher JB (2009) Agerelated changes in short-latency motor cortex inhibition. Exp Brain Res 198:489-500. CrossRef Medline

Smith MJ, Keel JC, Greenberg BD, Adams LF, Schmidt PJ, Rubinow DA, Wassermann EM (1999) Menstrual cycle effects on cortical excitability. Neurology 53:2069-2072. CrossRef Medline

Smyth C, Summers JJ, Garry MI (2010) Differences in motor learning suc- 
cess are associated with differences in M1 excitability. Hum Mov Sci 29:618-630. CrossRef Medline

Sohal VS, Zhang F, Yizhar O, Deisseroth K (2009) Parvalbumin neurons and gamma rhythms enhance cortical circuit performance. Nature 459: 698-702. CrossRef Medline

Stagg CJ, Bachtiar V, Johansen-Berg H (2011) The role of GABA in human motor learning. Curr Biol 21:480-484. CrossRef Medline

Stinear CM, Byblow WD (2003) Role of intracortical inhibition in selective hand muscle activation. J Neurophysiol 89:2014-2020. Medline

Tandonnet C, Garry MI, Summers JJ (2010) Cortical activation during temporal preparation assessed by transcranial magnetic stimulation. Biol Psychol 85:481-486. CrossRef Medline

van de Laar MC, van den Wildenberg WP, van Boxtel GJ, Huizenga HM, van der Molen MW (2012) Lifespan changes in motor activation and inhibition during choice reactions: a Laplacian ERP study. Biol Psychol 89: 323-334. CrossRef Medline

Vida I, Bartos M, Jonas P (2006) Shunting inhibition improves robustness of gamma oscillations in hippocampal interneuron networks by homogenizing firing rates. Neuron 49:107-117. CrossRef Medline

Vucic S, Cheah BC, Krishnan AV, Burke D, Kiernan MC (2009) The effects of alterations in conditioning stimulus intensity on short interval intracortical inhibition. Brain Res 1273:39-47. CrossRef Medline

Walther M, Berweck S, Schessl J, Linder-Lucht M, Fietzek UM, Glocker FX,
Heinen F, Mall V (2009) Maturation of inhibitory and excitatory motor cortex pathways in children. Brain Dev 31:562-567. CrossRef Medline

Wassermann EM (2002) Variation in the response to transcranial magnetic brain stimulation in the general population. Clin Neurophysiol 113:1165-1171. CrossRef Medline

Wehr M, Zador AM (2003) Balanced inhibition underlies tuning and sharpens spike timing in auditory cortex. Nature 426:442-446. CrossRef Medline

Yordanova J, Kolev V, Hohnsbein J, Falkenstein M (2004) Sensorimotor slowing with ageing is mediated by a functional dysregulation of motorgeneration processes: evidence from high-resolution event-related potentials. Brain 127:351-362. CrossRef Medline

Yu S, Wang Y, Li X, Zhou Y, Leventhal AG (2006a) Functional degradation of extrastriate visual cortex in senescent rhesus monkeys. Neuroscience 140:1023-1029. CrossRef Medline

Yu ZY, Wang W, Fritschy JM, Witte OW, Redecker C (2006b) Changes in neocortical and hippocampal GABAA receptor subunit distribution during brain maturation and aging. Brain Res 1099:73-81. CrossRef Medline

Ziemann U, Lönnecker S, Steinhoff BJ, Paulus W (1996a) The effect of lorazepam on the motor cortical excitability in man. Exp Brain Res 109: 127-135. Medline

Ziemann U, Lönnecker S, Steinhoff BJ, Paulus W (1996b) Effects of antiepileptic drugs on motor cortex excitability in humans: a transcranial magnetic stimulation study. Ann Neurol 40:367-378. CrossRef Medline 